A N N A L E S

UNIVERSITATIS MARIAE CURIE-SKŁODOWSKA

LUBLIN - POLONIA

VOL. LXV, 1

SECTIO G

2018

Doctoral student, Maria Curie-Skłodowska University, Lublin

maciek.moryc@gmail.com

\author{
MACIEJ MORYC
}

\title{
The Role of the Constitutional Court of the Russian Federation in the Enforcement of the European Court of Human Rights (ECHR) Decisions by Russia
}

Rola Sądu Konstytucyjnego Federacji Rosyjskiej w wykonywaniu przez Rosję wyroków Europejskiego Trybunału Praw Człowieka

Following the collapse of the Soviet Union, as a result of democratic processes and the inclination towards the West as prevailing in the emerging Russian Federation, the State authorities made a decision on Russia's accession to the Council of Europe (CE). The accession procedure commenced on 7 May 1992, with Russia's submitting a formal request to the CE. In response, the CE sent its representatives to the Russian Federation to investigate the actual status of the complying with human rights in that country. They found that the protection granted to human rights under Russian legislation, and Russia's "entering the democracy path", were both more theoretical than practical. ${ }^{1}$ The first visit by CE representatives was soon followed by others, all of which led to similar conclusions.

The first problem with Russia's accession to the Council of Europe appeared in 1995 in connection with the First Chechen War, and on 2 February 1995 the accession procedure was suspended. It was soon recommenced under Resolution 1065 of 27 September 1995, based on Moscow's undertaking, to search for the politically viable ways of solving the Chechen conflict. Russia was eventually

1 B. Bouring, Вступление России в Совет Европы и Защита Прав Человека: Всерьез Ли Выполняются Обязательства?, http://www.hrights.ru/text/b10/Chapter5.htm, publication date missing, [access: 23.05.2017]. 
admitted to the Council of Europe on 28 February 1996, officially becoming the $39^{\text {th }}$ CE Member. On 25 January 1996, 164 deputies of the Parliamentary Assembly of the Council of Europe voted for Russian accession to the CE, with 35 votes against and 15 abstentions. The opponents justified their decision by referring to the limited observance of human rights in the Russian Federation, and to the continuation of imperial Soviet policies, reflected in acts of aggression towards Chechnya. ${ }^{2}$

When joining the Council of Europe, Russia undertook to abide by the European Convention on Human Rights and Fundamental Freedoms (ratified by Russia in 1998, hereinafter "the Convention") and recognised the jurisdiction of the European Court of Human Rights in Strasbourg. Many experts stressed that the Russian Federation was receiving a credit of trust on its accession, having failed to satisfy some of the CE standards. For instance, the following observations were made during the UN inspection of Russian penal institutions and detention wards,

The Special Envoy would need Dante's poetic talent and Bosch's artistic skills to accurately depict the infernal conditions he encountered in these cells. Intensified feelings of smell, touch, taste and vision. The conditions are cruel, inhumane and degrading; they are themselves torture. Since the suspects are being held there to speed up investigations by breaking their will, in order to obtain confessions and information, they might as well be considered they are being tortured. ${ }^{3}$

Despite such observations, it was commonly believed that Moscow would take measures to fully implement the CE values through appropriate amendments to its national laws. Unfortunately, the sceptical voices soon proved to be right, with Moscow - which only a couple of years later entered an authoritarian path - being less willing to comply with its obligations. Coupled with the aggressive Russian foreign policy, this led to increasingly strong conflicts between the Russian Federation and the Council of Europe, on the one hand, and between the Russian Federation and the ECHR, on the other. These conflicts soon reached the point at which the enforcement of ECHR decisions was viewed by the Kremlin as directly impinging on its political and economic interests. This forced the State authorities to establish an effective political and legal tool which would not only enable but also justify Russia's failure to comply with ECHR rulings. This function was eventually entrusted to the Constitutional Court (CC) of the Russian Federation.

On 18 November 2010, during the International Forum on Constitutional Justice in St Petersburg, Valery Zorkin, Chairman of the Russian CC, objected to the "politicisation" of some of the ECHR rulings, threatening that the Russian Federation would withdraw from the Convention. This statement had probably

2 Ibidem.

3 Ibidem. 
been discussed in detail with the Russian authorities, and its objective was, firstly, to put the ECHR under pressure before the expected verdict in the case of shareholders in Yukos - a crude oil giant, accusing Russia of the unlawful acquisition of the company. Secondly, it was meant to pave the ideological and normative way for the subsequent failure to comply with the ECHR decision on this matter (with the verdict's being rightly assumed to disfavour Moscow). Strictly speaking, the Chairman of the Russian CC advocated that Russia did not have to treat the ECHR verdicts related to sovereignty as binding. ${ }^{4}$ Through Zorkin's speech, Russia clearly expressed its dissatisfaction with the ECHR's accepting the complaint filed by the Russian opposition against the course of the 2003 Parliamentary elections, and the Court's judgement in the case of a Russian soldier requesting that the same single-parent rights be granted to men as to women (i.e. the right to a three-year child care leave).

This clearly marked the beginning of the process of creating specific tools to enable the Russian Federation not to enforce some of the ECHR rulings, which eventually led to amending the Act on the Constitutional Court of the Russian Federation dated 14 December 2015. This process was accompanied by a fierce media campaign conducted by Zorkin, who zealously justified the increasing conflict between Russia and the ECHR in his several articles. Zorkin unambiguously presented himself as the follower of the Russian law's supremacy over any international treaties. He claimed that the provisions of the Russian Constitution, which envisaged the supremacy of international law over the national one,${ }^{5}$ did not imply any automatic "delegation of sovereignty", and that this "supremacy" did not refer to the Constitution itself. ${ }^{6}$ He nonetheless stressed that the Convention formed part of the Russian legal system. Zorkin was also critical of the European school of law, as rooted in Roman law, which he considered too detailed and casuistic. According to Zorkin, the interpretation of the law should be "consistent with both its letter and its spirit", which should allow the recognition of adequate contexts. ${ }^{7}$

In another article, Zorkin made a straightforward statement that "participation of the Russian Federation in the international treaty does not mean

4 "Russia vs. the European Court of Human Rights", published: 24.11.2010, https://www. osw.waw.pl/print/18901 [access: 20.05.2017].

5 Article $15 \S 4$ of the Russian Constitution states: "The universally-recognised norms of international law and international treaties and agreements of the Russian Federation shall be a component part of its legal system. If an international treaty or agreement of the Russian Federation establishes other rules than those envisaged by law, the rules of the international agreement shall be applied".

6 http://www.vedomosti.ru/politics/articles/2015/05/28/594165-valerii-zorkin-priznalprioritet-konstitutsii, published: 28.05.2015, [access: 24.01.2017].

7 W. Zorkin, Law and only law, "Rossijskaja Gazeta", published: 23.03.2015, https:// rg.ru/2015/03/23/zorkin-site.html [access: 24.01.2017]. 
abandoning its sovereignty, the legal expression of which is the supremacy of the Constitution". 8

Elaborating on this standpoint, Zorkin referred to the fear that, following the will of most CE Member States, the States initially unwilling to comply might eventually recognise the rights of transgender people, or the right to avoid mandatory military service. He further objected to the "activistic" practice of the ECHR, which allegedly forced its decisions on CE member states. ${ }^{9}$ His objection regarding politicisation was also reflected in the following statement. "Very often, human rights and their protection, especially in recent times, become tools for manipulating and resolving political issues and problems. Therefore, we must do everything to eliminate the dangerous trend of the politicisation of the application of the Convention [on Human Rights and Fundamental Freedoms] and a slide towards a cold war". ${ }^{10}$

In addition, in the same article, the Chairman of the Russian $\mathrm{CC}$ criticised "the law-making function of the ECHR", using the following words: "I have already said more than once that the law-making function of the ECHR as a supranational judicial body, which is not inscribed in the system of checks and balances inherent in democratic States, within the framework of the separation of powers, suffers from a lack of democratic legitimacy". ${ }^{11}$ Zorkin thus objected to one of the key rulings passed by the ECHR in the case of Tyrer vs. the United Kingdom, ${ }^{12}$ reflecting the fact that the evolutive doctrine was based on the wellestablished notion that the Convention is a living instrument which must be interpreted according to present-day conditions. ${ }^{13}$ This leads to the conclusion that Russian problems with enforcing ECHR rulings mainly stem from the lack of political will. The Kremlin's gradual entry to an authoritarian path, along with the annexation of Crimea and the outbreak of the armed conflict in the Donbas, had taken the Russian Federation to the point at which it felt compelled to secure its political and economic interests, fearing defeat in the crucial and prestigious cases pending before the ECHR. These fears appear justified in the light of the ECHR annual report, revealing that 7821 complaints had been lodged against the Russian Federation in 2016, placing it in fourth position among the sued States, with an approximately $10 \%$ share of the total number of complaints filed with the

8 W. Zorkin, Russia and Strasbourg, "Rossijskaja Gazeta", published: 21.10.2015, http:// rg.ru/2015/10/21/zorkin.html [access: 24.01.2017].

9 Ibidem.

10 Ibidem.

11 Ibidem.

12 Case No. 5856/72 "Tyrer vs. the United Kingdom".

13 B. Liżewski, Application of law in legal order of the Council of Europe, "Studia Iuridica Lublinensia” 2015, t. XXIV, nr 2. 
ECHR in 2016. ${ }^{14}$ The challenge of avoiding the enforcement of "inconvenient" ECHR rulings was entrusted to the Russian CC and to Zorkin, a former member of the Communist Party of the Soviet Union and a keen follower of the socage ideas, invariably enjoying much trust from the Kremlin.

The Russian Constitutional Court draws its mandate from the Constitution of the Russian Federation adopted on 12 December 1993 through a referendum, and taking effect on 25 December 1993. The whole of Chapter 7 of the Constitution deals with judicial power. The issues of the Constitutional Court are dealt with in Art. 125 and 128. The extensive provisions of Art. 125 determine the $\mathrm{CC}$ composition ${ }^{15}$ and competences, which include considering cases on the correspondence of the indicated laws with the Constitution, resolving disputes on jurisdiction matters, indicating the binding interpretation of the Constitution provisions, and providing, at the request of the Council of the Federation, a conclusion on the observance of the fixed procedure for advancing charges of treason or of other grave crimes against the President of the Russian Federation. ${ }^{16}$

14 The ECHR annual report for 2016, as of 31 December 2016, p. 192. The document is available at: http://www.echr.coe.int/Documents/Annual_report_2016_ENG.pdf. The total number of complaints received in 2016 amounted to 79750 . The most complaints were filed against Ukraine (18 171), Turkey (12 575) and Hungary (8 962).

15 The number of CC judges was determined to be 19.

16 Art. $125 \S 2$ of the Constitution of the Russian Federation: "The Constitutional Court of the Russian Federation upon requests of the President of the Russian Federation, the Council of the Federation, the State Duma, one fifth of the members of the Council of the Federation or of the deputies of the State Duma, the Government of the Russian Federation, the Supreme Court of the Russian Federation and the Higher Arbitration Court of the Russian Federation, the bodies of legislative and executive power of the subjects of the Russian Federation shall consider cases on the correspondence to the Constitution of the Russian Federation of: a) federal laws, normative acts of the President of the Russian Federation, the Council of the Federation, the State Duma, the Government of the Russian Federation; b) the constitutions of republics, charters, and also the laws and other normative acts of subjects of the Russian Federation adopted on issues under the jurisdiction of the bodies of state authority of the Russian Federation or under the joint jurisdiction of the bodies of state authority of the Russian Federation and the bodies of state authority of the subjects of the Russian Federation; c) treaties concluded between the bodies of state authority of the Russian Federation and the bodies of state authority of the subjects of the Russian Federation, treaties concluded between the bodies of state authority of the subjects of the Russian Federation; d) international treaties and agreements of the Russian Federation which have not come into force. $\S 3$. The Constitutional Court of the Russian Federation shall resolve disputes on jurisdiction: a) between the federal bodies of state authority; b) between the bodies of state authority of the Russian Federation and the bodies of state authority of the subjects of the Russian Federation; c) between the higher bodies of state authority of the subjects of the Russian Federation. § 4. The Constitutional Court of the Russian Federation, upon complaints about violations of constitutional rights and freedoms of citizens and upon court requests shall check, according to the rules fixed by federal law, the constitutionality of a law applied or subject to be applied in a concrete case. $\S 5$. The Constitutional Court of the Russian Federation, upon the requests of the President of the Russian Federation, the Council of the Federation, the State Duma, 
Art. 128 determines, inter alia, the mode of appointing Constitutional Court judges, while making reference to Federal Constitutional Law as providing more detailed regulations on the competences, mode of establishment and activities of the Constitutional Court.

It should also be noted that the Constitution of the Russian Federation vests in Russian citizens the right to have their cases examined by a court, including the right to resort to international tribunals responsible for the protection of human rights and freedoms. This directly arises from Art. $46 \S 3$ of the Constitution, under which "Everyone shall have the right to appeal, according to international treaties of the Russian Federation, to international bodies for the protection of human rights and freedoms, if all the existing internal state means of legal protection have been exhausted". It, therefore, flows from the Constitution that referring a complaint to an international body is conditional on the prior exhausting of the internal means of legal protection and valid court decisions. This provision seems to have been enacted to facilitate the lodging of complaints with the ECHR, and it satisfies the formal requirements stipulated in the Convention. The conclusion can even be drawn that, by including such a provision in its Constitution, Russia has acknowledged that the system of the protection of human rights, as grounded in the Convention and the ECHR, constitutes the centre of the European human rights protection system which the Russian Federation joined on ratifying the Convention.

The Constitutional provisions on the $\mathrm{CC}$ were further developed in the Federal Constitutional Law of 21 July 1994 on the Constitutional Court of the Russian Federation (voting in the State Duma took place on 24 June 1994, and in the Council of the Federation, i.e. the upper house of the Russian Parliament, on 12 July 1994). The Law failed to envisage any role of the CC in the processing of cases against the Russian Federation referred to international courts and tribunals. However, as the conflict between Russia and the Council of Europe intensified, the $\mathrm{CC}$ was vested with the power to adjudicate on Russia's enforcement, or failure to enforce rulings passed by international bodies.

Following the amendments of 14 December 2015 to the Law on the Constitutional Court of the Russian Federation, the CC was granted the power to make conclusions on whether the verdicts issued by international bodies,

the Government of the Russian Federation, the bodies of the legislative power of the subjects of the Russian Federation, shall give its interpretation of the Constitution of the Russian Federation. $\S 6$. Acts or their provisions recognised as unconstitutional shall become invalid; international treaties and agreements not corresponding to the Constitution of the Russian Federation shall not be liable to enforcement and application. § 7. The Constitutional Court of the Russian Federation, upon the request of the Council of the Federation, shall provide a conclusion on the observance of the fixed procedure for advancing charges of treason or of another grave crime against the President of the Russian Federation". 
responsible for adjudicating on matters of the protection of human rights and freedoms, complied with the Constitution of the Russian Federation ${ }^{17}$. Paragraph 3.2 was added to Art. 3, reading as follows:

Shall, upon requests by federal executive body competent to operate in the field of protecting Russia's sovereign interests within the procedure of considering complaints filed against the Russian Federation, which is carried out by the interstate human rights protection institution according to an international covenant to which Russia is a party, resolve the issue of feasibility of the enforcement of the interstate human rights protection institution's decision.

The Russian executive authorities (including in particular the Ministry of Justice) were thus officially allowed to refer to the Constitutional Court any decisions passed by international courts and tribunals which, in their opinion, impinged on the political or economic interests of the Russian Federation.

Under the newly-adopted provisions, on 19 April 2016, the CC, at the request of the Minister of Justice, found that the ECHR judgement dated 4 July 2013, in the case of Anchugov and Gladkov vs. Russia (complaints Nos. 11157/04 and 15162/05), forcing Russia to amend its regulations which deprived citizens serving jail sentences of the right to vote, ${ }^{18}$ contradicted the Constitution of the Russian Federation. The ECHR judgement was seen as violating Art. $32 \S 3$ of the Constitution, stipulating that "Citizens recognised by court as legally unfit, as well as citizens kept in places of confinement under a court sentence, shall be deprived of the right to elect and be elected", in the part referring to citizens kept in prisons under valid judicial decisions. It is worth stressing that the arguments put forward by the Russian Federation before the ECHR were also grounded in the notion of the supremacy of the principal Act over international laws. The ECHR did not recognise those arguments as valid.

17 Federal Constitutional Law of 14 December 2015 N 7-ФК3 on introducing amendments to the Federal Constitutional Law on the Constitutional Court of the Russian Federation.

${ }^{18}$ An identical issue had previously arisen, inter alia, in the complaints filed against the United Kingdom (Judgement of the Grand Chamber of the ECHR of 6 October 2005 in the case of Hirst vs. the United Kingdom [No. 2], complaint No. 74025/01, ECHR 2005-IX; ECHR Judgement of 23 November 2010 in the case of Greens and M.T. vs. the United Kingdom, complaints Nos. 60041/08 and 60054/08) and Italy (Judgement of the Grand Chamber of the ECHR of 22 May 2012 in the case of Scoppola vs. Italy [No. 3], complaint No. 126/05). The objections raised by prisoners concerned their right to free vote, protected under Art. 3 of Protocol No. 1. In the ground-breaking judgement passed in the case of Hirst vs. the United Kingdom [No. 2], the Strasbourg Court ruled that the ban on all prisoners' exercising the right to vote, merely because of serving their sentence, was contrary to the Convention's standards. This position was upheld in the subsequent rulings: http://www.hfhr. pl/europejska-konwencja-praw-czlowieka-a-rosyjska-konstytucja-komentarz-do-wyroku-etpcz-wsprawie-anchugov-i-gladkov-przeciwko-rosji/ [access: 21.05.2017]. 
The CC judgement gave rise to strong criticism, being considered a dangerous precedent. ${ }^{19}$ Along with the common "politicisation"-related accusations, the judgement was viewed as directly violating the undertakings made by the Russian Federation following its accession to the CE. The wording of Art. 46 of the Convention unambiguously obliges the Signatory States to implement ECHR rulings. It was further stressed that, on signing the Convention, Russia had made no objections as to the limited or conditional enforcement of ECHR judgements. ${ }^{20}$

Russia can also be accused of violating the Vienna Convention on the law of treaties, the provisions of which (and, more specifically, of its Art. 27) unambiguously stipulate "[a] party may not invoke the provisions of its internal law as justification for its failure to perform a treaty". In addition, the ECHR, when justifying its judgements, strongly affirmed that the provisions of the Convention were supreme to national regulations, regardless of the internal hierarchy of legal Acts, as nationally applied, and it has consistently upheld its jurisprudence. ${ }^{21}$

19 This was not the first ECHR judgement which the Russian Federation refused to enforce. It had also refused to comply with the judgement passed in the case of Catan vs. Russia and Moldova (complaints Nos. 43370/04, 18454/06 and 8252/05) of 19 October 2012, in which the ECHR considered the right to pursue education in the Romanian language by a resident of the separatist Transdniestria. In the course of judgement enforcement control by the Committee of Ministers of the Council of Europe, the Russian Federation stated that it would not accept the judgement or pay the damages adjudicated in favour of the claimant - I.C. Kamiński, Suspending the Rights of the Russian Delegation in the Parliamentary Assembly of the Council of Europe, published: 02.02.2015, http://www.hfhr.pl/zawieszenie-praw-rosyjskiej-delegacji-w-zgromadzeniu-parlamentarnym-radyeuropy/ [access: 23.05.2017].

20 Sz. Kardaś, Russia refuses to implement the judgement of the European Court of Human Rights, published: 20.04.2016, http://www.osw.waw.pl/print/24302 [access: 10.08.2016].

21 The Case of Anchugov and Gladkov v. Russia, Nos. 11157/04 and 15162/05: 50. The Court reiterates that Article 1 requires the States Parties to "secure to everyone within their jurisdiction the rights and freedoms defined in Section I of this Convention". That provision makes no distinction as to the type of rule or measure concerned, and does not exclude any part of the Member States' "jurisdiction" from scrutiny under the Convention (see Bosphorus Hava Yolları Turizm ve Ticaret Anonim Şirketi v. Ireland [GC], No. 45036/98, § 153, ECHR 2005 VI; Al-Saadoon and Mufdhi v. the United Kingdom, No. 61498/08, § 128, ECHR 2010 (extracts); and Nada v. Switzerland [GC], No. 10593/08, § 168, ECHR 2012). It is, therefore, with respect to their "jurisdiction" as a whole which is often exercised in the first place through the Constitution - that the States Parties are called on to show compliance with the Convention (see United Communist Party of Turkey and Others v. Turkey, 30 January 1998, § 29, Reports of Judgments and Decisions 1998 I); 108. The Court further notes the Government's argument that the present case is distinguishable from Hirst (No. 2), as in Russia a provision imposing a voting bar on convicted prisoners is laid down in the Constitution - the basic law of Russia adopted following a nationwide vote - rather than in an "ordinary" legal instrument enacted by a parliament, as was the case in the United Kingdom (...). In that connection the Court reiterates that, according to its established case-law, a Contracting Party is responsible under Article 1 of the Convention for all acts and omissions of its organs regardless of whether the act or omission in question was a consequence of domestic law or of the necessity to comply with international legal obligations (...). As noted in paragraph 50 above, Art. 1 makes no distinction 
As already mentioned, the $\mathrm{CC}$ ruling was precedential, and made room for the executive authorities of the Russian Federation to refer to the $\mathrm{CC}$ for review the ECHR decisions which they did not intend to comply with. Rather than all ECHR judgements' being referred to the $\mathrm{CC}$, this procedure was meant to be limited to those decisions which could potentially bring political or economic harm to Moscow. As had been expected, the Ministry of Justice of the Russian Federation queried the $\mathrm{CC}$ about the implementation, or failure to implement, the ECHR judgement in the case of the Yukos shareholders vs. Russia, ${ }^{22}$ obliging Russia to pay a record-breaking sum of EUR 1866104634 to the crude-oil giant as "just compensation" (damages for sustained losses), and another EUR 300000 to cover the legal costs incurred by the claimants. ${ }^{23}$ The Yukos case may be viewed as having provided the major incentive for the Russian Government to introduce the reference legislative amendments to the Law on the $\mathrm{CC}$, in order to facilitate the blocking of the implementation of international judgements disfavouring Russia.

The CC issued a decision on the Yukos case on 19 January 2017. Not surprisingly, it ruled that the Russian Federation could not implement the ECHR judgement. The essence of the 67-page-long justification very much corresponded to the statement made by Zorkin - "Russia is allowed not to fulfil the obligations imposed where such non-fulfilment constitutes the only way to prevent the violation of the Constitution of the Russian Federation". Although the justification was meant to present legal arguments, experts seem to agree that its content was politically orchestrated by the Kremlin.

Following the amendments to the Law on the CC in December 2015, the CC received prerogatives unprecedented on the European scale, enabling it to issue binding statements on whether the Russian Federation could or could not execute judgements by international bodies. The CC in the Russian Federation was thus placed in a privileged position in relation to any international judicial bodies, and Moscow received a useful tool to make the arbitrary selection of rulings issued by the ECHR (and other international tribunals) which it intended to comply with. This has, on the one hand, set a dangerous precedent, and, on the other, constituted a gross violation, on the part of Russia, of the standards of international law,

as to the type of rule or measure concerned, and does not exclude any part of a member State's "jurisdiction" - which is often exercised in the first place through the Constitution - from scrutiny under the Convention. The Court notes that this interpretation is in line with the principle set out in Art. 27 of the 1969 Vienna Convention on the Law of Treaties (...).

22 Complaint No. 14902/04.

23 At this point, it is worth referring to another case adjudicated by the Permanent Court of Arbitration (PCA) in the Hague, in which Yukos shareholders sued the Russian Federation. The case (No. 2005-03/AA226) ended in the PCA's issuing a decision obliging Russia to pay the astronomical amount of USD 50020867798 for the benefit of the claimants. The typescript containing the PCA justification of its decision was as many as 615 pages long. The implementation of the PCA judgement by the Russian Federation would mean bringing down the federal budget. 
especially in the light of the above-cited Art. 27 of the Vienna Convention on the law of treaties, excluding the possibility to invoke the provisions of national law in order to justify failure to fulfil treaty obligations. Moreover, the $\mathrm{CC}$ issued its decision under the full subordination, if not political servility, to the executive power. Although Russian courts formally enjoy independence, in reality they form the weakest element in the separation-of-powers model, and they hardly ever overtly act against the expectations of the other centres of political powers. This can be viewed as a follow-up to the Soviet traditions and political model.

On these grounds, the Russian Government may be rightly expected to continue referring "inconvenient" ECHR judgements to its CC with an attempt to procure decisions formally blocking their enforcement. A more far-reaching conclusion can also be made that the same will apply to the ECHR judgement to be passed in the Beslan case, ${ }^{24}$ obliging Russia to pay damages to victims' families, reaching nearly EUR 3000000.

\section{BIBLIOGRAPHY}

Bouring, В., Вступление России в Совет Европь и Защита Прав Человека: Всерьез Ли Выполняются Обязательства?, http://www.hrights.ru/text/b10/Chapter5.htm, publication date missing, [access: 23.05.2017].

Constitution of the Russian Federation.

Federal Constitutional Law on the Constitutional Court of the Russian Federation

http://www.hfhr.pl/europejska-konwencja-praw-czlowieka-a-rosyjska-konstytucja-komentarz-dowyroku-etpcz-w-sprawie-anchugov-i-gladkov-przeciwko-rosji/ [access: 21.05.2017].

http://www.vedomosti.ru/politics/articles/2015/05/28/594165-valerii-zorkin-priznal-prioritetkonstitutsii, published: 28.05.2015, [access: 24.01.2017].

Kamiński, I.C., Suspending the Rights of the Russian Delegation in the Parliamentary Assembly of the Council of Europe, published: 02.02.2015, http://www.hfhr.pl/zawieszenie-prawrosyjskiej-delegacji-w-zgromadzeniu-parlamentarnym-rady-europy/ [access: 23.05.2017].

Kardaś, Sz., Russia refuses to implement the judgement of the European Court of Human Rights, published: 20.04.2016, http://www.osw.waw.pl/print/24302 [access: 10.08.2016].

Liżewski, B., Application of law in legal order of the Council of Europe, "Studia Iuridica Lublinensia" 2015, t. XXIV, nr 2.

"Russia vs. the European Court of Human Rights", published: 24.11.2010, https://www.osw.waw.pl/ print/18901 [access: 20.05.2017].

Zorkin, W., Law and only law, "Rossijskaja Gazeta”, published: 23.03.2015, https://rg.ru/2015/03/23/ zorkin-site.html [access: 24.01.2017].

Zorkin, W., Russia and Strasbourg, "Rossijskaja Gazeta", published: 21.10.2015, http:// rg.ru/2015/10/21/zorkin.html [access: 24.01.2017].

${ }^{24}$ Complaint No. 26562/07 Tagayeva and others v. Russia, ETPC Judgement dated 13 April 2017. 


\section{SUMMARY}

The article describes accumulation of the conflict between the Russian Federation and the European Court of Human Rights. This process resulted in final implementation by the Russian Federation legal institutions, which legally allow not to implement ECHR's judgements, alleging them in contradiction of the Russian Constitution. The main role in this process started to perform Russian Constitutional Court (CC). CC, requested by the executive body, may decide that ECHR's judgment contradicts the Russian Constitution, which would result in lack of possibilities to execute such judgment. This kind of legal regulation is unprecedented among the legal systems of the Council of Europe member states, and poses a serious violation of international treaties, signed by the Russian Federation.

Keywords: European Court of Human Rights; Council of Europe; Russian Federation; constitutional court; Russian Constitutional Court; human rights in Russia

\section{STRESZCZENIE}

W artykule zostało opisane narastanie konfliktów między Federacją Rosyjską a Europejskim Trybunałem Praw Człowieka. Proces ten skutkował ostatecznie wdrożeniem przez Rosję instrumentów prawnych, pozwalających na niewykonywanie wybranych orzeczeń ETPC pod zarzutem ich niezgodności z rosyjską konstytucją. Główna rola w tym względzie przypadła rosyjskiemu Sądowi Konstytucyjnemu (SK). SK, na wniosek organu władzy wykonawczej, na gruncie obowiązujących przepisów może orzec o niezgodności orzeczenia ETPC z konstytucją FR, co w praktyce uniemożliwia skuteczną egzekucję takiego orzeczenia. Przyjęcie takiego rozwiązania jest niespotykane na gruncie prawodawstwa innych państw członkowskich Rady Europy oraz stanowi istotne pogwałcenie umów międzynarodowych, których Rosja jest stroną.

Słowa kluczowe: Europejski Trybunał Praw Człowieka; Rada Europy; Federacja Rosyjska; Rosja, sąd konstytucyjny; Trybunał Konstytucyjny Federacji Rosyjskiej; prawa człowieka w Rosji 
